\title{
Motivasi, Disiplin dan Lingkungan Kerja dalam Mempengaruhi Kinerja Pegawai
}

\author{
Impact of Work Motivation, Work Discipline and Work Environment on \\ Employee Performance
}

Oleh:

\author{
Nining Yuningsih; Adi Maryadi; Adibah Yahya; Nitis Sekar Kinanthi \\ Universitas Pelita Bangsa \\ nining.yuningsih@pelitabangsa.ac.id; adi.maryadi@pelitabangsa.ac.id; \\ adibah.yahya@pelitabangsa.ac.id; sekarkinanthi011297@gmail.com
}

\begin{abstract}
ABSTRAK
Penelitian ini bertujuan untuk mengetahui pengaruh motivasi, disiplin, dan lingkungan kerja terhadap kinerja karyawan. Karyawan PT. Mitrapak Eramandiri yang berjumlah 60 orang sebagai responden yang mengisi kuesioner. Alat analisis meliputi uji validitas, reliabilitas, asumsi klasik, $T$, dan F diolah menggunakan SPSS 22. Hasil penelitian menunjukan bahwa motivasi dan disiplin berpengaruh positif dan signifikan terhadap kinerja karyawan, sedangkan lingkungan kerja tidak berpengaruh terhadap kinerja karyawan.
\end{abstract}

Kata Kunci : Motivasi kerja, Disiplin Kerja, Lingkungan Kerja dan Kinerja.

\section{ABSTRACT}

This research aims to determine the influence of motivation, discipline, and work environment on employee performance. Employees of PT. Mitrapak Eramandiri numbered 60 people as respondents who filled out questionnaires. Analytical tools include tests of validity, reliability, classical assumptions, $T$, and F processed using SPSS 22. The results showed that motivation and discipline had a positive and significant effect on employee performance, while the work environment had no effect on employee performance.

Keywords: work motivation, Work Discipline, Work Environment and Empleyee Performance.

\section{PENDAHULUAN}

Tujuan perusahaan didirikan dalam rangka mningkatkan jumlah kekayaan atau dengan kata lain memaksimalkan laba. Keuntungan yang dicapai tidak terlepas dari semua aspek operasional maupun non operasional. Ketika perusahaan dapat dikelola dengan baik, maka keuntungan tersebut dapat dicapai.
Peran sumber daya manusia sangat penting dalam meningkatkan efisiensi dan efektivitas perusahaan (Wahyudi, 2019).

Perusahaan selalu mengharaplan sumber daya manusia yang berkualitas, yang mampu bekerja dengan profesional serta dapat mencapai tujuan dari perusahaan. Kinerja karyawan merupakan faktor penilaian keberhasilan perusahaan. Ketika kinerja karyawan tinggi maka dapat 
meningkatkan produktivitas, sehingga tujuan perusahaan dapat tercapai.

Konsep pengukuran kinerja merupakan salah satu ukur kemampuan pegawai dalam melaksanakan kewenangannya. Banyak hal yang dapat mempengaruhi kinerja pegawai yang baik antara lain adalah motivasi, disiplin kerja pegawai, pengawasan, gaya kepemimpinan dan lain sebagainya (Hasibuan \& Silvya, 2019).

Kinerja tinggi merupakan salah satu keunggulan kompetitif perusahaan. Kinerja sangat tergantung pada sumber daya manusia yang tinggi dan moral yang baik (Siswadi \& Lestari, 2021). Sumber daya manusia dapat menjalankan pekerjaannya dengan memiliki semangat kerja. Semangat kerja dapat ditumbuhkan melalui motivasi. Karyawan dapat memenuhi tugasnya dengan adanya motivasi yang merupakan keadaan dimana seseorang melakukan kegiatan tertentu secara sadar untuk mencapai tujuan. Motivasi berasal dari diri sendiri, adapun motivasi kerja merupakan semangat seorang karyawan dalam menjalankan pekerjaannya sesuai standar atau bahkan melampaui (Siswadi \& Lestari, 2021).

Dalam suatu organisasi, motivasi setiap individu pasti berbeda-beda. Oleh karena itu organisasi diharapkan untuk memberikan kesempatan dalam pemenuhan kebutuhan para pekerjanya. Motivasi dapat mendorong seseorang untuk melaksanakan tugasnya secara maksimal, sehingga mencerminkan peningkatan kinerja karyawan (Amri et al, 2021). Namun berbeda dengan (Sari, 2016) yang menyatakan bahwa motivasi tidak mempengaruhi kinerja karyawan di PT Patra Komala Dumai. Hal ini menunjukkan bahwa perusahaan yang berbeda menunjukkan kinerja yang berbeda pula.

Seorang karyawan yang profesional tidak bisa lepas dari kenyataan bahwa mereka adalah individu yang juga memiliki kebutuhan, keinginan, dan harapan dari pekerjaan. Keinginan untuk memenuhi kebutuhan ini akan mempengaruhi motivasi kerja yang ada pada setiap individu untuk melakukan segala sesuatu lebih baik dari yang lain dalam usahanya mencapai tujuan (Mangkunegara \& Octorend, 2015).

Hasil kinerja karyawan dapat diwujudkan melalui kedisiplinan karyawan. Disiplin kerja dapat digambarkan melalui ketaatan karyawan dalam mematuhi peraturan perusahaan dan norma-norma yang berlaku. Dibutuhkan kesadaran secara sukarela dalam memenuhi tugas dan tanggung jawabnya. Kedisiplinan menciptakan semangat kerja yang dapat berimbas pada kinerja karyawan. Semakin tinggi kedisiplinan seseorang, maka dia dapat melaksanakan pekerjaan tanpa paksaan sehingga dapat meningkatkan kinerja (Amri et al., 2021), (Yusnandar \& Hasibuan, 2021), (Iskamto et al, 2020). Namun disiplin kerja tidak dapat memediasi pengaruh motivasi kerja terhadap kinerja karyawan (Jufrizen \& Sitorus, 2021).

Peningkatan kinerja karyawan juga didukung oleh faktor lingkungan kerja. Adaptasi terhadap lingkungan kerja merupakan hal yang penting, dimana kondisi lingkungan yang baik atau sesuai dapat mendukung pelaksanaan kegiatan dengan rasa aman dan nyaman (Putri, et al, 2019).

Keadaan aman dan nyaman dapat memberikan kepuasan dan mendorong semangat kerja, sehingga dapat meningkatkan kinerja karyawan. Kinerja yang baik merupakan pendorong bagi karyawan untuk memajukan organisasi menjadi lebih baik (Yusnandar \& Hasibuan, 2021).

Pengamatan yang dilakukan oleh penulis di PT Mitrapak Eramandiri pada bulan Juni-Juli 2021 (minggu ke 34-38) dari total jumlah karyawan sebanyak 60 orang, dengan data sebagaimana tabel 1. 
Tabel 1. Tingkat presensi karyawan PT Mitrapak Eramandiri

\begin{tabular}{|c|c|c|c|c|c|}
\hline \multirow{2}{*}{ Week } & \multicolumn{4}{|c|}{ Absensi } & \multirow{2}{*}{ Jumlah } \\
\hline & Sakit & Ijin & Cuti & Alpa & \\
\hline 34 & 6 & 7 & 9 & - & 22 \\
\hline 35 & 7 & 4 & 8 & 1 & 20 \\
\hline 36 & 4 & 5 & 7 & - & 16 \\
\hline 37 & 10 & 9 & 8 & 1 & 28 \\
\hline 38 & 7 & 6 & 9 & 2 & 24 \\
\hline
\end{tabular}

Sumber: PT Mitrapak Eramandiri, data diolah 2021

Dari data tabel 1, dapat diketahui bahwa kemangkiran karyawan meningkat terutama di minggu ke 37 dan 38. Hal ini mengindikasikan terjadinya undisipliner, kurangnya semnagt kerja, dan kondisi lingkungan kerja yang kurang nyaman sehingga karyawan lebih memilih tidak masuk kerja dibandingkan bekerja dengan sungguh-sungguh.

Permasalahan yang dihadapi perusahaan, serta adanya inkonsistensi penelitian mengenai pengaruh disiplin kerja, motivasi kerja, dan lingkungan kerja terhadap kinerja karyawan mendorong penulis untuk mengkaji dan menganalisis pengaruh disiplin kerja, motivasi kerja, dan lingkungan kerja terhadap kinerja karyawan di PT Mitrapak Eramandiri.

\section{METODOLOGI}

\section{Pengembangan Model \\ Kinerja Karyawan}

Kinerja adalah fungsi dari motivasi dan kemampuan. Dibutuhkan motivasi dan kemampuan dalam menyelesaikan tugas atau pekerjaan. Motivasi dan kemampuan seseorang tidak cukup efektif untuk melakukan sesuatu tanpa pemahaman yang jelas tentang apa yang harus dilakukan dan bagaimana melakukannya (Ghozali, 2017).

Kesediaan dan keterampilan seseorang tidaklah cukup efektif untuk mengerjakan suatu pekerjaan tanpa pemahaman yang jelas tentang apa yang dikerjakan dan bagaiman mengerjakannya. Kinerja merupakan pencapaian persyaratan pekerjaan tertentu yang akhirnya secara langsung dapat tercermin dari keluaran yang dihasilkan (Iskamto et al, 2020). Faktor-faktor yang mempengaruhi kinerja menurut Griffin (2000) dalam (Efendi et al, 2020) adalah tiga hal: 1). Kemampuan, 2). Motivasi, 3). Lingkungan.

Kinerja karyawan dipengaruhi oleh disiplin, motivasi, dan lingkungan kerja. Lingkungan kerja yang nyaman dapat menciptakan kedisiplinan karyawan. Kedisiplinan tumbuh atas dasar motivasi. Kinerja karyawan dapat tercapai dengan baik jika karyawan memiliki tingkat disiplin yang tinggi (Supriyanto et al, 2020), (Amri et al., 2021), (Yusnandar \& Hasibuan, 2021). Karyawan yang memiliki motivasi kerja yang tinggi dapat menunjukkan kinerja yang tinggi pula (Siswadi \& Lestari, 2021), (Musa et al, 2021). Dukungan lingkungan kerja yang nyaman dan fasilitas yang memadai dapat meningkatkan kinerja karyawan (Supriyanto et al., 2020), (Putri et al., 2019), (Prastiyo, 2019).

\section{Motivasi Kerja}

Motivasi sebagai suatu usaha positif dalam menggerakkan, mengerahkan dan mengarahkan daya dan potensi tenaga kerja agar secara produktif berhasil mencapai dan mewujudkan tujuan yang telah ditetapkan sebelumnya dan sebagai perangsang untuk menggerakkan, mengerahkan dan mengarahkan potensi serta daya kerja manusia tersebut kearah yang diinginkan (Musa et al, 2021).

Faktor-faktor yang mempengaruhi motivasi dapat dilihat dalam teori dua faktor Herzberg, (1) Faktor Hygiene yang 
meliputi gaji, kehidupan pribadi, kualitas pengawasan, kondisi kerja, keamanan kerja, hubungan interpersonal, kebijakan dan administrasi perusahaan dan (2) Faktor Motivasi yang terkait dengan konten pekerjaan termasuk kesuksesan, pengakuan, pekerjaan yang menantang, kemajuan dan pertumbuhan dalam pekerjaan (Siswadi \& Lestari, 2021).

Tingginya tingkat motivasi yang dimiliki oleh karyawan merupakan salah satu kunci dalam meningkatkan kinerja karyawan (Mangkunegara \& Octorend, 2015), (Hermina \& Yosepha, 2019), (Ghozali, 2017).

H1: Terdapat pengaruh motivasi kerja terhadap kinerja karyawan PT Mitrapak Eramandiri

\section{Disiplin Kerja}

Disiplin menunjukkan suatu kondisi atau sikap hormat yanga da pada diri karyawan terhadap peraturan dan ketetapan perusahaan. Dengan demikian jika peraturan atau ketetapan yang ada dalam perusahaan dijalankan dengan baik, menggambarkan kondisi disiplin yang baik. Begitupula sebaliknya, tindakan pengabaian atas ketetapn dan peraturan menunjukkan disipin kerja yang buruk (Sutrisno, 2009).

Disiplin adalah salah satu jalan yang ditempuh organisasi, untuk memastikan mencapai tujuan perlu alat, dan alat yang efektif adalah membuat aturan. Meski tidak ada jamin tercapainya tujuan, namun upaya harus tetap dilakukan. Rasa percaya diri tersebut tertuang dalam berbagai kebijakan dan prosedur, bahkan termasuk mengatur sikap dan perilaku karyawan (Wahyudi, 2019).

Pada dasarnya karyawan menyadari bahwa disiplin kerja merupakan kunci keberhasilan yang harus dilaksanakan dan harus dilaksanakan oleh setiap individu agar disiplin kerja yang baik akan memberikan kelancaran dalam proses menjalankan suatu pekerjaan dan juga akan tercapainya hasil kerja yang maksimal di dalam perusahaan (Iskamto et al, 2020).
Faktor-faktor yang mempengaruhi disiplin kerja (Hasibuan, 2014) adalah sebagai berikut: 1). Tujuan dan kemampuan, 2). Keteladanan kepemimpinan, 3). Keadilan, 4). Pengawasan, 5). Sanksi pinalti, 6). Ketegasan, 7). Hadiah, 8). Hubungan manusia.

Disiplin yang tinggi akan meningkatkan kinerja pegawai atau organisasi; Disiplin mencerminkan besarnya rasa tanggung jawab seseorang terhadap tugas-tugas yang dibebankan kepadanya. Setiap peningkatan kinerja akan dipengaruhi oleh disiplin kerja (Amri et al., 2021), (Siswadi \& Lestari, 2021), (Yusnandar \& Hasibuan, 2021).

H2: Terdapat pengaruh disiplin kerja teradap kinerja karyawan PT Mitrapak Eramandiri.

\section{Lingkungan Kerja}

Menurut Barry Render \& Jay Haeizer (2001), lingkungan kerja merupakan lingkungan fisik tempat karyawan bekerja yang mempengaruhi kinerja, keamanan dan mutu kehidupan kerja mereka. Lingkungan kerja menurut (Sedarmayanti, 2009) adalah "keseluruhan alat perkakas dan bahan yang dihadapi, lingkungan sekitarnya dimana seseorang bekerja, metode kerjanya, serta pengaturan kerjanya baik sebagai perseorangan maupun sebagai kelompok" (Sudaryo, Aribowo, \& Sofiati, 2018).

Indikator pengukuran lingkungan kerja menurut (Sedarmayanti, 2009) adalah: (1) lingkungan kerja fisik, yaitu segala sesuatu yang bersifat fisik dan tampak di sekitar tempat kerja yang secara langsung atau tidak langsung dapat mempengaruhi kinerja karyawan. Lingkungan kerja dibagi menjadi dua kategori, lingkungan yang berhubungan langsung dengan karyawan dan perantara, atau lingkungan global yang juga dapat merujuk pada lingkungan kerja. lingkungan kerja yang mempengaruhi kondisi manusia; (2) Lingkungan kerja non fisik yaitu segala keadaan yang berhubungan dengan hubungan karyawan, baik dengan atasan, rekan kerja, 
maupun bawahan (Ekowati, Supriyanto, \& Aldi, 2020).

Lingkungan kerja yang baik, fasilitas yang memadai, dan tempat kerja yang kondusif serta hubungan yang baik dengan rekan kerja dan atasan akan memberikan kenyamanan bagi karyawan dan mendorong karyawan bekerja lebih baik, sehingga kinerja karyawan dapat meningkat (Putri et al., 2019), (Supriyanto et al., 2020), (Prastiyo, 2019).

H3: Terdapat pengaruh lingkungan kerja teradap kinerja karyawan PT Mitrapak Eramandiri

\section{Jenis Penelitian}

Penelitian ini menggunakan metode kuantitatif, metode ini merupakan pendekatan ilmiah untuk melihat apakah suatu fakta dapat diklasifikasikan, diukur, diamati, dan spesifik (Sugiyono, 2017). Selain itu data penelitian berupa angkaangka yang nantinya akan dianalisis menggunakan statistik. Penelitian ini bertujuan untuk mengetahui pengaruh motivasi, disiplin kerja dan lingkungan kerja terhadap kinerja karyawan pada PT Mitrapak Eramandiri.

Tabel 2. Definisi operasional variabel

\begin{tabular}{|c|c|c|}
\hline Variabel & Instrumen & Skala \\
\hline $\begin{array}{l}\text { Kinerja Karyawan (Y) } \\
\text { (Syafrina, 2017) }\end{array}$ & $\begin{array}{l}\text { 1) Kualitas } \\
\text { 2) Kuantitas } \\
\text { 3) Jangka waktu } \\
\text { 4) Hubungan antar karyawan }\end{array}$ & Interval 1-5 \\
\hline $\begin{array}{l}\text { Motivasi Kerja (X1) } \\
\text { (Lie \& Siagian, 2018) }\end{array}$ & $\begin{array}{l}\text { 1) Perilaku Karyawan } \\
\text { 2) Usaha karyawan } \\
\text { 3) Kegigihan karyawan }\end{array}$ & Interval 1-5 \\
\hline $\begin{array}{l}\text { Disiplin Kerja (X2) } \\
\text { (Yani, 2019) }\end{array}$ & $\begin{array}{l}\text { 1) Tujuan dan Kemampuan } \\
\text { 2) Teladan pimpinan } \\
\text { 3) Balas jasa } \\
\text { 4) Keadilan } \\
\text { 5) Pengawasan melekat (waskat) } \\
\text { 6) Sanksi hukum } \\
\text { 7) Ketegasan } \\
\text { 8) Hubungan kemanusiaan }\end{array}$ & Interval 1-5 \\
\hline $\begin{array}{l}\text { Lingkungan Kerja (X3) } \\
\text { (Aoliso \& Lao, 2018) }\end{array}$ & $\begin{array}{l}\text { 1) Cahaya atau Penerangan } \\
\text { 2) Suhu udara } \\
\text { 3) Kebisingan } \\
\text { 4) Hubungan kerja }\end{array}$ & Interval 1-5 \\
\hline
\end{tabular}

Sumber: dari berbagai sumber, data diolah 2021

Penelitian ini menggunakan analisis penelitian non probability sampling yang merupakan teknik pengambilan sampel yang tidak memberi peluang atau kesempatan yang sama bagi setiap unsure atau anggota populasi untuk dipilih menjadi sampel.

Teknik sampling yang digunakan adalah teknik sampling jenuh, yaitu teknik pengambilan sampel bila semua anggota digunakan sebagai sampel. Istilah lain sampel jenuh adalah sensus, dimana semua anggota populasi dijadikan sampel. Sampel jenuh sering diartikan sampel sudah maksimum, ditambah berapapun tidak akan merubah keterwakilan (Sugiyono, 2017). Jumlah sampel sebanyak 60 karyawan PT Mitrapak Eramandiri yang merupakan populasi penelitian.

Untuk melakukan pengujian analisis, karyawan PT Mitrapak Eramandiri mengisi kuesioner dengan jawaban yang 
telah disediakan menggunakan skala likert 1-5, dengan kriteria 1 sangat tidak setuju dan 5 sangat setuju. Penaksiran ini untuk mendapatkan verifikasi dalam bentuk dukungan empiris data dilapangan, karena data yang disajikan berupa angka dan menggunakan analisis statistik. selanjutnya data di analisa : 1) uji validitas dan reliabilitas, 2). uji asumsi, 3).uji model dan 4).uji hipotesis (Junedi, Yahya, \& Sari, 2021).

Tabel 3. Hasil Uji Validitas dan Reliabilitas

\begin{tabular}{|c|c|c|c|c|}
\hline No & Variabel & $\begin{array}{l}\text { Cronbach's } \\
\text { Alpha; r-hitung }\end{array}$ & Nilai kritis & Keterangan \\
\hline \multirow[t]{10}{*}{1} & Motivasi (X1) & 0,773 & 0,600 & Reliabel \\
\hline & X1.1 & 0,815 & 0,254 & Valid \\
\hline & $\mathrm{X} 1.2$ & 0,623 & 0,254 & Valid \\
\hline & X1.3 & 0,808 & 0,254 & Valid \\
\hline & X1.4 & 0,720 & 0,254 & Valid \\
\hline & X1.5 & 0,807 & 0,254 & Valid \\
\hline & X1.6 & 0,702 & 0,254 & Valid \\
\hline & $\mathrm{X} 1.7$ & 0,676 & 0,254 & Valid \\
\hline & X1.8 & 0,616 & 0,254 & Valid \\
\hline & X1.9 & 0,660 & 0,254 & Valid \\
\hline \multirow[t]{9}{*}{2} & Disiplin Kerja (X2) & 0,776 & 0,600 & Reliabel \\
\hline & $\mathrm{X} 2.1$ & 0,661 & 0,254 & Valid \\
\hline & $\mathrm{X} 2.2$ & 0,773 & 0,254 & Valid \\
\hline & $\mathrm{X} 2.3$ & 0,699 & 0,254 & Valid \\
\hline & $\mathrm{X} 2.4$ & 0,779 & 0,254 & Valid \\
\hline & $\mathrm{X} 2.5$ & 0,640 & 0,254 & Valid \\
\hline & $X 2.6$ & 0,784 & 0,254 & Valid \\
\hline & $\mathrm{X} 2.7$ & 0,815 & 0,254 & Valid \\
\hline & $\mathrm{X} 2.8$ & 0,592 & 0,254 & Valid \\
\hline \multirow[t]{11}{*}{3} & Lingkungan Kerja (X3) & 0,736 & 0,600 & Reliabel \\
\hline & $\mathrm{X} 3.1$ & 0,515 & 0,254 & Valid \\
\hline & $\mathrm{X} 3.2$ & 0,450 & 0,254 & Valid \\
\hline & X3.3 & 0,652 & 0,254 & Valid \\
\hline & X3.4 & 0,550 & 0,254 & Valid \\
\hline & X3.5 & 0,388 & 0,254 & Valid \\
\hline & X3.6 & 0,583 & 0,254 & Valid \\
\hline & X3.7 & 0,659 & 0,254 & Valid \\
\hline & X3.8 & 0,628 & 0,254 & Valid \\
\hline & X3.9 & 0,643 & 0,254 & Valid \\
\hline & X3.10 & 0,607 & 0,254 & Valid \\
\hline \multirow[t]{9}{*}{4} & Kinerja $(\mathrm{Y})$ & 0,775 & 0,600 & Reliabel \\
\hline & Y.1 & 0,733 & 0,254 & Valid \\
\hline & Y.2 & 0,766 & 0,254 & Valid \\
\hline & Y.3 & 0,771 & 0,254 & Valid \\
\hline & Y.4 & 0,584 & 0,254 & Valid \\
\hline & Y.5 & 0,784 & 0,254 & Valid \\
\hline & Y.6 & 0,734 & 0,254 & Valid \\
\hline & Y.7 & 0,594 & 0,254 & Valid \\
\hline & Y.8 & 0,750 & 0,254 & Valid \\
\hline
\end{tabular}

Sumber: output SPSS, data diolah 2021 


\section{HASIL PENELITIAN}

\section{Uji Validitas dan Reliabilitas}

Validitas merupakan suatu instrumen atau tes ditentukna berdasarkan dat ahasil ukur instrumen yang bersangkutan, baik melalui uji coba maupun tes atau pengukuran sesungguhnya. Validitas adalah tingkat kesesuaian suatu batasan konseptual yang diberikan dengan bantuan operasional yang telah dikembangkan, sedangkan reliabiloitas adalah keajegan pengukuran. Dengan kata lain reliabilitas merupakan konsistensi suatu alat pengukur dalam mengukur gejala yang sama secara tepat.

Jika r-hitung > r-tabel, maka kuesioner tersebut dianggap valid, sebaliknya jika rhitung < r-tabel kuesioner dinyatakan tidak sah. R-tabel dengan jumlah responden $n=60$, pada tingkat signifikansi $5 \%$ adalah 0,254 .

Uji reliabilitas yang digunakan yaitu Cronbach's Alpha, dimana variabel dikatakan reliabel jika nilainya $>0,600$. Berikut hasil tes uji validitas dan reliabiitas atas kuesioner yang telah disebar kepada karyawan PT Mitrapak Eramandiri.

\section{Uji asumsi klasik}

Analisis linear berganda digunakan dalam penelitian ini dengan tujuan untuk mengetahui ada tidaknya pengaruh variabel bebas terhadap variabel terikat. Persyaratan penting untuk terpenuhi dalam model regresi adalah tidak adanya multikolinearitas. Metode pengambilan keputusan yaitu jika semakin kecil nilai Tolerance dan VIF maka semakin mendekati terjadinya masalah multikolinearitas. Hasil uji menyatakan bahwa data yang diolah terbebas dari multikolinearitas, karena nilai tolerance lebih dari 0,1 dan niai VIF kurang dari 10.

\section{Uji Model}

Kemampuan besaran model berdasarkan padan nilai $\mathrm{R}$ Square (koefisien determinasi) Pengujian dengan uji $F$ dan uji $t$ merupakan pengujian atas hipotesis penelitian. Jika nilai signifikansi < 0,05 maka model dapat diterima.

Nilai Adj R Square dari tabel 5 sebesar 0,639 menunjukkan pengaruh motivasi kerja, disiplin kerja, dan lingkungan kerja sebesar 63,9\% terhadap kinerja karyawan.

Nilai F hitung sebesar 71,847 dan sig F sebesar 0,000 menunjukkan bahwa secara simultan motivasi kerja, disiplin kerja, dan lingkungan kerja berpengaruh terhadap kinerja karyawan.

Nilai uji signifikansi atas uji hipotesis parsial motivasi kerja dan disiplin kerja terhadap kinerja karyawan sebesar 0,000 menunjukkan pengaruh yang signifikan. Sedangkan nilai atas variabel lingkungan kerja sebesar 0,827 menunjukkan bahwa variabel lingkungan kerja tidak berpengaruh terhadap kinerja karyawan.

Tabel 4. Ringkasan uji asumsi klasik

\begin{tabular}{|c|c|c|c|}
\hline Variabel & Tolerance & VIF & Simpulan \\
\hline Motivasi & ,404 & 2,474 & \\
\hline Disiplin & ,274 & 3,652 & Bebas Multikolinearitas \\
\hline Lingkungan & ,482 & 2,075 & \\
\hline
\end{tabular}

a. Dependent Variable: Kinerja Karyawan

Sumber: output SPSS, data diolah 2021 
Tabel 5. Ringkasan uji hipotesis dan regresi berganda

\begin{tabular}{lrrrr}
\hline \multicolumn{1}{c}{ Variabel } & Koefisien Regresi & t & \multicolumn{2}{c}{ Sig } \\
\hline (Constant) & & 8,387 & 4,098 &, 000 \\
Motivasi &, 498 & 6,932 &, 000 \\
Disiplin & &, 183 & 2,259 &, 026 \\
Lingkungan &, 012 &, 207 &, 837 \\
\hline \multicolumn{1}{c}{ R Square } & Adj R Square & F Hitung & Sig F \\
\hline 0,648 & & 0,639 & 71,847 & 0,000 \\
\hline
\end{tabular}

\section{PEMBAHASAN}

Pengaruh motivasi kerja, disiplin kerja, dan lingkungan kerja terhadap kinerja karyawan

Motivasi terbentuk dari sikap dalam menghadapi situasi kerja, sehingg aterbentuk energi atau semangat untuk mencapai tujuan organisasi (Dewi, 2018). Karyawan yang memiliki motivasi tinggi cenderung memiliki tingkat kinerja yang tinggi. Motivasi dapat menciptakan kedisiplinan kerja, karyawan yang disiplin dan mentaati peraturan cenderung memiliki kinerja yang baik. Lingkungan kerja yang mendukung dapat meningkatkan kinerja karyawan.

Hasi uji model dengan tingkat signifikansi 0,05 menunjukkan nilai signifikan sebesar 0,000. Dapat disimpulkan bahwa variabel motivasi kerja, disiplin kerja, dan lingkungan kerja secara simultan berpengaruh terhadap kinerja karyawan.

\section{Pengaruh motivasi kerja terhadap kinerja karyawan}

Motivasi merupakan aspek yang sangat penting yang harus diperhatikan manajemen jika seluruh karyawan ingin berkontribusi secara aktif terhadap pencapaian tujuan perusahaan. Dengan motivasi, karyawan melakukan tugas yang diberikan dengan semmangat yang tinggi. Tanpa motivasi, karyawan tidak dapat memenuhi tugasnya sesuai standar atau bahkan melebihi standar karena motif dan motivasinya dalam bekerja tidak terpenuhi (Siswadi \& Lestari, 2021).

Hasil uji hipotesis menunjukkan bahwa nilai signifikansi atas variabel motivasi kerja terhadap kinerja karyawan sebesar 0,000 yang berarti bahwa motivasi kerja berpengaruh signifikan terhadap kinerja karyawan. Hal ini sesuai dengan penlitian yang dilakukan oleh (Mangkunegara \& Octorend, 2015), (Hermina \& Yosepha, 2019), (Ghozali, 2017)

\section{Pengaruh disiplin kerja terhadap kinerja karyawan}

Tujuan organisasi tidak dapat dicapai tanpa disiplin kerja karyawannya. Adanya disiplin kerja yang baik akan mempengaruhi dan menciptakan kondisi kerja yang baik bagi peningkatan kinerja karyawan (Mangkunegara, 2011). Peningkatan disiplin pada setiap bagian dalam pengelolaan sumber daya manusia sebagai faktor penting yang mempengaruhi peningkatan kinerja.

Hasil uji hipotesis menunjukan nilai signifikansi sebesar $0,000<0,05$, yang berarti bahwa disiplin kerja berpengaruh signifikan terhadap kinerja karyawan. Semakin baik disiplin kerja karyawan maka akan menciptakan peningkatan kinerja karyawan. Hal ini sejalan dengan (Mangkunegara \& Octorend, 2015), (Amri et al., 2021), (Siswadi \& Lestari, 2021), (Yusnandar \& Hasibuan, 2021). 


\section{Pengaruh lingkungan kerja terhadap kinerja karyawan}

Lingkungan kerja yang mendukung diharapkan dapat merangsang produktivitas karyawan. Karyawan harus menjalankan tugas sesuai dengan tugas dan fungsinya di perusahaan (Dewi, 2018). Selain itu karyawan dapat berinteraksi dengan lingkungan dan rekan kerja dengan karakter yang berbeda sehingga dapat meningkatkan kinerja karyawan (Prastiyo, 2019).

Hasil uji hipotesis menunjukkan nilai signifikansi sebesar $0,837>0,05$, yang menyatakan bahwa lingkungan kerja tidak berpengaruh terhadap kinerja karyawan. Hal ini berarti bahwa baik buruknya lingkungan tidak mempengaruhi peningkatan kerja karyawan. Hal ini sejalan dengan penelitian (Logahan \& Tjoe, 2013).

\section{SIMPULAN}

Motivasi kerja berpengaruh positif dan signifikan terhadap kinerja karyawan. Disiplin kerja berpengaruh positif dan signifikan terhadap kinerja karyawan. Lingkungan kerja tidak berpengaruh terhadap kinerja karyawan;

Terdapat berbagai keterbatasan dalam penelitian sehingga hasilnya tidak dapat memberikan gambaran yang komprehensif. (1) Terdapat variabel lain yang belum diteliti yang dapat mempengaruhi kinerja pegawai. Sehingga memungkinkan peneliti lain untuk meneliti masalah yang sama dengan menambahkan variabel bebas lainnya. (2) Lingkungan kerja berkaitan dengan suarasuara bising serta dekorasi ruangan pada perusahaan yang dapat merusak konsentrasi dalam bekerja, sehingga semangat menjadi turun yang berakibat pada penurunan kinerja karyawan.

\section{DAFTAR PUSTAKA}

Amri, A., Ramadhi, R., \& Ramdani, Z. (2021). EFFECT OF ORGANIZATION COMMITMENT, WORK MOTIVATION AND WORK DISCIPLINE ON EMPLOYEE PERFORMANCE (Study at. PT. PLN (Persero) P3b Sumatera UPT Padang). International Journal of Educational Management and Innovation, 2(1), 88. https:// doi.org/10.12928/ijemi.v2i1.3183

Aoliso, A., \& Lao, H. (2018). Pengaruh Lingkungan Kerja Terhadap Kepuasan Kerja Karyawan Pada PT.TASPEN(Persero) Kantor Cabang Kupang. BISMAN, Jurnal Bisnis \& Manajemen, m(1). https://doi.org/10.35697/jrbi.v3i2.937

Dewi, M. A. (2018). Pengaruh Penerapan Iso 9001:2008, Motivasi, Kemampuan, Dan Lingkungan Kerja Terhadap Kinerja Karyawan Puskesmas Surabaya Dengan Employee Engagement Sebagai Variabel Moderating. Makro: Jurnal Manajemen Dan Kewirausahaan, 3(1), 1-21. https://doi.org/10.36467/makro.2018.03.01.01

Efendi, R., Rifa'i, M. N., Bahrun, K., Milla, H., \& Suharmi. (2020). The Mediation Of Work Motivation On The Effects Of Work Discipline and Compensation On Performance Batik Msmes Employees in Yogyakarta City, Indonesia. International Journal of Multicultural and Multireligious Understanding, 7(1), 689-703. Retrieved from http://dx.doi.org/10.18415/ijmmu.v7i1.1375

Ekowati, V. M., Supriyanto, A. S., \& Aldi, S. (2020). Predicting Modelling of Factors Influencing Innovative Work Behavior. Technium Social Sciences Journal, 10, 465-477. Retrieved from https://techniumscience.com/index.php/socialsciences/article/view/332/124

Ghozali, I. (2017). Pengaruh Motivasi Kerja, Kepuasan Kerja dan Kemampuan Kerja Terhadap Kinerja Pegawai Pada Kantor Kementrian Agama Kabupaten Banjar. Jurnal Ilmiah Ekonomi Bisnis, 3(1), 130-137.

Hasibuan, J. S., \& Silvya, B. (2019). Pengaruh Motivasi Kerja Dan Disiplin Kerja Terhadap Kinerja Karyawan. Inovasi Produk Penelitian Pengabdian Masyarakat Dan Tantangan Era Revolusi 4.0 Industri, 2(1), 134-147. https://doi.org/10.31227/osf.io/9frzv

Hasibuan, M. S. (2014). Manajemen Sumber Daya Manusia (Revisi) (Revisi). Jakarta: Bumi Aksara.

Hermina, U. N., \& Yosepha, S. Y. S. (2019). The model of employee motivation and cooperative employee performance. International Review of Management and Marketing, 9(3), 69-73. https://doi.org/10.17512/pjms.2019.20.2.32 
Iskamto, D., Yapentra, A., Budi Ansori, P., \& Jupri, M. (2020). Effect of Working Discipline Toward Performance: An Empirical Investigation. KnE Social Sciences, 2020, 492-501. https://doi.org/10.18502/kss.v4i9.7347

Jufrizen, J., \& Sitorus, T. S. (2021). Pengaruh Motivasi Kerja dan Kepuasan Kerja Terhadap Kinerja Dengan Disiplin Kerja Sebagai Variabel Intervening. Prosiding Seminar Nasional Teknologi Edukasi Sosial Dan Humaniora, 1(1), 841-856.

Junedi, Yahya, A., \& Sari, D. (2021). Pengaruh Gaya Kepemimpinan, Efektivitas Organisasi dan Gaya Negosiasi Terhadap Inovasi Produk UMKM Hijab di Kabupaten Bekasi. Syntax Literate: Jurnal Ilmiah Indonesia, 6(12), 6189-6196.

Lie, T. F., \& Siagian, H. (2018). Pengaruh Kepuasan Kerja Terhadap Kinerja Karyawan Melalui Motivasi Kerja Pada Cv. Union Event Planner. Agora, 6(1), 1-6.

Logahan, J. M., \& Tjoe, T. F. (2013). Kompensasi Terhadap Kinerja Karyawan CV MUM INDONESIA Konsep Lingkungan Kerja , Kompensasi , dan Kinerja. Binus Business Review, 3(1), 573-586.

Mangkunegara, A. P. (2011). Manajemen Sumber Daya Manusia Perusahaan. Bandung: PT. Remaja Rosdakarya.

Mangkunegara, A. P., \& Octorend, T. R. (2015). Effect of Work Discipline, Work Motivation and Job Satisfaction on Employee Organizational Commitment in the Company (Case Study in PT. Dada Indonesia). Universal Journal of Management, 3(8), 318-328. https://doi.org/10.13189/ujm.2015.030803

Musa, F. N. H., Tumbel, A., \& Wullur, M. (2021). Discipline Analysis Of Work, Motivation And Loyalty Towards Employee Performance (Case Study At Gorontalo State University). Aksara: Jurnal Ilmu Pendidikan Nonformal, 7(2), 449. https:// doi.org/10.37905/aksara.7.2.449-462.2021

Prastiyo, F. D. (2019). Pengaruh Stres Kerja, Lingkungan Kerja dan Motivasi Kerja Terhadap Kinerja Karyawan Pada PT JNE Cabang Madiun. SIMBA: Seminar Inovasi Manajemen, Bisnis Dan Akuntansi, 18(1), 23.

Putri, E. M., Ekowati, V. M., Supriyanto, A. S., \& Mukaffi, Z. (2019). the Effect of Work Environment on Employee Performance Through Work Discipline. International Journal of Research GRANTHAALAYAH, 7(4), 132-140. https://doi.org/10.29121/granthaalayah.v7.i4.2019.882

Sari, Y. K. (2016). Pengaruh Kepemimpinan, Motivasi Dan Disiplin Kerja Terhadap Kinerja Karyawan Pada Pt. Patra Komala Di Dumai. Jurnal Tepak Manajemen Bisnis, VI(2), 119-127.

Sedarmayanti. (2009). Sumber Daya Manusia dan Produktivitas Kerja. Bandung: CV Mandar Maju.

Siswadi, Y., \& Lestari, D. (2021). Effect of Work Motivation, Emotional Intellegence and Work Dicipline on Employee Performance. International Journal of Economics, Technology and Social Sciences, 2(1), 227-237.

Sudaryo, Y., Aribowo, A., \& Sofiati, N. A. (2018). Manajemen Sumber Daya Manusia Kompensasi Tidak Langsung dan Lingkungan Kerja Fisik (T. Erang, Ed.). Yogyakarta: Penerbit ANDI.

Sugiyono, P. D. (2017). Metodologi Penelitian Kuantitatif Kualitatif dan R\&D. Bandung: Alfabeta.

Supriyanto, A. S., Ekowati, V. M., \& Vironika, H. (2020). Linking work environment to employee performance: the mediating role of work discipline. BISMA (Bisnis Dan Manajemen), 13(1), 14. https://doi.org/10.26740/bisma.v13n1.p14-25

Sutrisno, E. (2009). Manajemen Sumber Daya Manusia (p. 244). p. 244. Jakarta: Kencana.

Syafrina, N. (2017). Pengaruh Disiplin Kerja Terhadap Kinerja Karyawan Pada PT. Suka Fajar Pekan Baru. Eko Dan Bisnis (Riau Economics and Business Review), 4(8), 1-12. Retrieved from https://ekobis.stieriau-akbar.ac.id/index.php/Ekobis/article/view/5

Wahyudi. (2019). Pengaruh Disiplin Dan Motivasi Terhadap Kinerja Karyawan. Scientific Journal Reflection: Economic, Accounting, Management and Business, 2(3), 351-360. https://doi.org/10.31227/osf.io/4g2nx

Yani, M. (2019). PENGARUH GAYA KEPEMIMPINAN DAN DISIPLIN KERJA TERHADAP PRESTASI KERJA KARYAWAN PADA PT. DWI MITRA ADHIUSAHA DI SAMPIT. E-Jurnal Profit (Jurnal Penerapan Ilmu Manajemen Dan Kewirausahaan), 4(1), 74-89.

Yusnandar, W., \& Hasibuan, J. S. (2021). The Role of Employee Performance Regarding the Effect of Work Discipline and Leadership. International Journal of Economics, Technology and Social Sciences, 2(1), 189-203. 